\title{
Do Public R\&D Expenditures Foster Business R\&D Investments?
}

Do Public R\&D Expenditures Foster Business R\&D Investments?

\author{
Tomasz Kijek \\ Faculty of Economics \\ Maria Curie-Sktodowska University in Lublin, Poland \\ tomasz.kijek@poczta.umcs.lublin.pl
}

Anna Matras-Bolibok

Faculty of Agrobioengineering

University of Life Sciences in Lublin, Poland

anna.matras@up.lublin.pl

Elwira Rycaj

Marshal Office of Lubelskie Region, Poland

elwira.rycaj@hbelskie.pl

\begin{abstract}
Purpose - The aim of the paper was to assess the relationship between public R\&D expenditures and business R\&D investments in EU regions.

Design/Methodology/Approach - The data for the analysis were retrieved from the Regional Innovation Scoreboard (RIS) 2016. The generalized structural equation model - GSEM was adopted to verify the formulated hypothesis. The research sample covered 214 regions of $22 \mathrm{EU}$ Member States and Norway.

Findings - The results of research indicate that public $R \& D$ are additional to business $R \& D$ investments in EU regions. Moreover, innovative productivity is positively related to public financial support for R\&D.

Originality/Value - So far, most of the available empirical literature has focused on the relationship between public financial support policies for R\&D activities and business R\&D expenditures either at the macro or micro level. The present paper attempts to fill this gap by providing an insight into this matter at the regional level.
\end{abstract}

Article type - Research paper.

Keywords - R\&D activity, R\&D expenditures, innovation, public subsidies, UE regions.

\section{Introduction}

Research and development (R\&D) activity, as a first stage of innovation process, is characterised by high risk resulting from low predictability of the results of conducted researches and relatively long gestation period. Additionally, the features of R\&D outputs are approximation and inequality and absence of recurrence. These factors

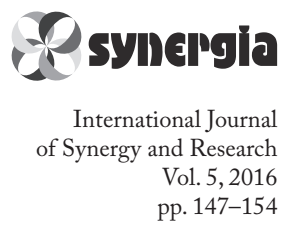


IJSR 5 imply, therefore, that investors demand higher rate of return that leads to increase of the cost of undertaking innovation activities. Given the limited access and high cost of external capital, firms have to finance R\&D largely with equity.

It is commonly considered, however, that it is difficult to finance R\&D with equity in a competitive economy (Hall and Lerner, 2010). Theoretical background of this view is that knowledge, being the primary output of resources devoted to invention, is nonrival: use by one firm does not preclude its use by another (Arrow, 1962). To the extent that knowledge cannot be kept secret, the returns to the investment in knowledge cannot be appropriated by the firm undertaking the investment and bearing its risk. Market imperfections and unsatisfactory real protection from imitation by competitors discourage entities from investing in risky and costly innovation activities. Moreover, running R\&D projects financed with equity is highly dependent on the level of firm's liquidity (Czarnitzki et al., 2011). Liquidity constraints may restrain firms from undertaking innovation activities, especially in the case of the small and medium-size enterprises, which are usually characterised by limited financial resources. These aforementioned conditions, may lead to an insufficient level of R\&D investment in the economy.

As innovations play a key role in fostering economic development, the possibility of insufficient supply of R\&D investments creates the need for policy intervention and public financial support. Given the prior arguments, a common practice in developed industrial countries is an innovation policy aiming at fostering $R \& D$ activities. According to Eurostat (2016), the share of public R\&D expenditures was equal about $32 \%$ in the European Union, nearly $30 \%$ in the United States, and about $15 \%$ in Japan. Furthermore, a sizeable amount of these public funds is actually used to subsidise R\&D activities undertaken by private firms (Alonso-Borrego et al., 2012).

Another argument for public financial support for R\&D activities is that knowledge created in innovation process is considered as a public good as one person's use of knowledge does not diminish its utility to another. Additionally, R\&D activities generate positive externalities, connected with higher social rates of return in comparison to private ones.

Bearing in mind a key role of R\&D activities in economic development and an undisputed need for public support in that field, the major research question arises as to whether the public R\&D subsidies are either complementary and stimulate companyfinanced R\&D or they substitute the private $R \& D$ investments, thus, crowding them out. So far, most of the available empirical literature has focused on the relationship between public financial support policies for $R \& D$ activities and business $R \& D$ expenditures either at the macro or micro level. The present paper attempts, therefore, to fill this gap by providing an insight into this matter at the regional level.

The aim of the paper is to assess the relationship between the public R\&D expenditures and private $R \& D$ investments. The remainder of the paper is composed as follows. Section 2 presents the review of the relevant literature on the relationship between the public R\&D expenditures and private R\&D investments. Section 3 describes the methodological issues of the research and data collection procedures. Section 4 discusses the empirical results of the study. The paper is closed with conclusions in Section 5 , providing the key findings of the study and some suggestions for the directions of future research. 


\section{The relationship between public and private expenditures}

The foundations for public support for innovativeness were established by the endogenous growth theory (Shaw, 1992). Contrary to the neoclassical growth models, in which the technological progress was concerned to be an exogenous and independent variable (Solow, 1957), endogenous growth is driven by technological change that results from the R\&D efforts. This assumptions implicate that subsidies to R\&D could contribute to improvement of innovativeness and may impact the long-run rate of economic growth (Romer, 1990; Jones, 1995).

Given the undisputable role of public support for innovation activities, the major research question has been present in economic debate as to whether the public R\&D subsidies are either complementary and additional to business R\&D or they substitute for and, thus, crowd out private R\&D. The findings of an extensive review of the relevant literature from the period of over 30 years focusing on this relationship conducted by David et al. (2000) are ambiguous. Also in a more recent study, Alonso-Borrego et al. (2012), reviewing over five decades of prior research, found mixed empirical evidence, so the question whether public funding is a stimulant or not for private investments is far from having a conclusive answer. However, several studies argue that there is no evidence of a crowding out effect and some attest that, without public funds, firms would have invested significantly less of their own funds in R\&D activities (e.g. González and Pazó, 2008; Clausen, 2009; Czarnitzki and Bento, 2012).

The reason for the expectation that public R\&D expenditures should not displace private $R \& D$ investments is that direct $R \& D$ subsidies are usually focused on projects that offer high marginal social rates of return to investments in knowledge, and in the fields where large gap between the social and private rate of return could be observed (David et al., 2000). As Alonso-Borrego et al. (2012) point out, the additional effect of public subsidies on private $R \& D$ investment will be stronger in financially constrained firms and in small and young firms. This is due to the fact that public R\&D subsidies shall diminish the negative effect of financial constraints on private R\&D activities. AliYrkkö (2005) demonstrates that financially constrained companies are more likely to use public subsidies to finance riskier but promising R\&D projects that would otherwise be dismissed or postponed.

All prior presented arguments have led us to put forward the following research hypothesis:

H1: Public R\&D expenditures stimulate private R\&D investments.

It could be expected that the character of relationship between public and private $R \& D$ efforts is shaped by many factors. These factors could be divided into two groups: internal (like firm's size, age, level of profitability and liquidity, type of industry) and external (connected with firm's activity environment). As Garcia-Quevedo (2004) states, the level of analysis also determines the impact of R\&D subsidies on business performance. He found a weak evidence supporting this view, i.e. that micro-level studies show the existence of crowding out effects, contrary to industry- or countrylevel. Görg and Strobl (2007) investigated the impact of the amount of subsidies on the private $R \& D$ efforts with conclusion that for domestic plants small grants serve to
Do Public R\&D

Expenditures

Foster Business

R\&D

Investments? 
IJSR 5

increase private $R \& D$ spending, while too large grants may crowd out private financing of R\&D.

The stimulating effect of public R\&D financial subsidies on private $R \& D$ investments might be also shaped by several factors determining the innovation absorptive capacity of the firms and regions in which they operate. Among these factors we could distinguish human capital, as it enables the absorption, imitation and creation of innovations. Without well-educated and experienced population these processes will not proceed effectively or will not occur at all. Also, it could be expected that the stimulating effect should appear in the locations characterised by high level of relational capital, as it enhances the propensity to apply for public financial support and benefiting from them. Undertaking collaboration enables access to external knowledge and funds and contributes to improvement of firms innovation performance.

Most of the empirical literature has focused on the impact of public financial support on business R\&D activities using R\&D expenditures as the outcome variable. As Hall and Lerner (2010) point out the focus on R\&D instead of the broader concept of innovation investment is largely due to considerations of measurement feasibility and data availability. However, as government intervention appears to induce higher business expenses, it is worth assessing their effectiveness. The evidence in economic literature dealing with this issue are ambiguous. As Mandl et al. (2008) point out, the efficiency in public spending on R\&D varies significantly between countries. Moreover, public funding with a civilian objective actually has a positive effect on the elasticity of business $R \& D$ and that government funding is successful in enhancing business $R \& D$ with higher social returns. Simultaneously, the defence-related part of public funding seems to have a significant negative impact on the effectiveness of business R\&D (Guellec and van Pottelsberghe de la Potterie, 2004). However, the results of analysis conducted by Catozzella and Vivarelli (2011) show that the efficiency associated with public R\&D expenditures is affected negatively, at least as far as product innovations are concerned. Supported firms revealed lower innovative productivity, measured with the ratio between total innovative sales and total innovative expenditures, than nonsupported ones.

Apart from aforementioned arguments it is worth to point out that the effectiveness of $R \& D$ policies requires adequate level of regional development. As Cabrer-Borrás and Serrano-Domingo (2007) conclude, the combination of innovation policy instruments with other policies focused on the improvement of socio-economic and structural determinants of regional innovativeness would be recommended.

\section{Data and methods}

We retrieved data from the Regional Innovation Scoreboard (RIS) 2016 which provides a comparative assessment of innovation performance across 214 regions of 22 EU Member States and Norway. The RIS 2016 replicates the European Innovation Scoreboard methodology used at national level to measure performance of regional systems of innovation. Most of the RIS indicators are fractional indicators with values between $0 \%$ and $100 \%$, and most of these follow a normal distribution. Some indicators are unbound indicators, where values are not limited to an upper threshold. Due to data 
availability we used normalized indicators. The normalization was performed by using the min-max procedure. First, the minimum score observed for all regions across all observations had been subtracted from the respective transformed score. The rest was next divided by the difference between the maximum and minimum scores observed for all regions across all observations. The maximum normalised score is equal to 1 and the minimum normalised score is equal to 0 .

Table 1 provides a description of the variables used in our study. It also contains information on the measurement of variables and their coding.

\begin{tabular}{ll}
\hline Variable & Description \\
\hline PUB_RD & R\&D expenditures in the public sector as percentage of GDP \\
\hline PRIV_RD & R\&D expenditures in the business sector as percentage of GDP \\
\hline HUM_CAP & Percentage population aged 30-34 having completed tertiary education \\
\hline INN & SMEs introducing product or process innovations as percentage of SMEs \\
\hline
\end{tabular}

Source: Authors' own compilation.

In order to verify the formulated hypothesis, we decided to use the generalized structural equation model - GSEM. Structural equation modelling can be viewed as a combination of several traditional multivariate procedures, such as factor analysis, regression analysis, discriminant analysis or canonical correlation (Bagozzi and Yi, 2012). Our empirical model consists of two equations. The former and the latter were estimated using censored regression models (Greene, 2008). The choice of the censored regression models results from the nature of the dependent variables which are double censored, i.e. they range between 0 and 1 . In the first equation the dependent variable is PRIV_RD. This equation includes PUB_RD and HUM_CAP among regressors. In the second equation the dependent variable is INN. It contains PRIV_RD and PUB_RD among regressors. The two-equation model is specified as follows:

$$
\begin{gathered}
P R I V_{-} R D_{i}=\alpha_{11} P U B_{-} R D_{i}+\alpha_{12} H U M_{-} C A P_{i}+\varepsilon_{i} \\
I N N_{i}=\alpha_{22} P U B_{R D_{i}}+\alpha_{23} P R I V_{R D_{i}}+\varepsilon_{i}
\end{gathered}
$$

\section{Results and discussion}

Table 2 shows the results of the GSEM parameters estimation. As expected, the public R\&D intensity appears to be stimulating the private $R \& D$ intensity, as the parameter for the variable PUB_RD is positive and significant in the first equation. As far as the human capital variable is considered, the results indicate that there is a positive and significant relationship between the percentage population aged 30-34 having completed tertiary education and R\&D expenditures in the business sector. This result confirms the fact that human capital plays a key role in innovation process.

Considering the second equation we can find that the private R\&D expenditures have a positive impact on innovation performance. The similar results are reported by
Do Public R\&D

Expenditures

Foster Business

R\&D

Investments?

Table 1.

List of variables and their description 


\section{IJSR}

5

Table 2.

GSEM parameters estimation

\begin{tabular}{lcccc}
\hline Variable & Coef. & Std. err. & $z$ & $P>|z|$ \\
\hline PRIV_RD & & & & \\
\hline PUB_RD & 0.251 & 0.046 & 5.39 & 0.000 \\
\hline HUM_CAP & 0.129 & 0.047 & 2.71 & 0.007 \\
\hline CONST & 0.077 & 0.025 & 3.14 & 0.002 \\
\hline INN & & & & \\
\hline PRIV_RD & 0.299 & 0.091 & 3.29 & 0.001 \\
\hline PUB_RD & 0.467 & 0.064 & 7.24 & 0.000 \\
\hline CONST & 0.219 & 0.025 & 8.71 & 0.000 \\
\hline Log likelihood & 622,555 & & & \\
\hline
\end{tabular}

Source: Authors' own compilation.

Martin (2014). The public R\&D expenditures do affect directly the firms' propensity to innovation, what is consistent with arguments presented in the literature (Radicic et al., 2016). We may also notice that the public outlays on R\&D stimulate innovation performance in the indirect way. As mentioned previously, the public R\&D expenditures affect the private investments in R\&D. As such, the private R\&D outlays have a moderating effect on the link between the public R\&D investments and innovation performance.

\section{Conclusions}

The nature of R\&D activity and its crucial role in shaping innovativeness and development of economies imply the necessity for public policy intervention in that field. One of the main innovation policy instruments are financial subsidies, aiming at supporting R\&D processes, commonly adopted by developed, industrial economies.

The results of research of present paper indicate that public R\&D expenditures impact positively business R\&D investments in EU regions. Supported firms indeed appear to increase their innovative expenditures, so we can conclude that public subsidies are additional to firms spending on R\&D. Moreover, their innovative effectiveness is positively related to public financial support for R\&D.

These findings support the view of the development strategy Europe 2020 for EU member countries (European Commission, 2010), aiming at improving their innovativeness, in particular by increasing combined public and private investment in R\&D.

It is worth pointing out, however, that effectiveness of $R \& D$ policies requires adequate level of regional development. Moreover, the stimulating effect of public R\&D financial subsidies on private R\&D investments is shaped by several factors determining the innovation absorptive capacity of the regional economies. Incorporation of these factors into analysis of the relationship between public and private R\&D expenditures sets out some directions of future research. 


\section{References}

Alonso-Borrego, C., Forcadell, F. J., Galán-Zazo, J. I. and Zúñiga-Vicente, J. A. (2012). Assessing the Effect of Public Subsidies on Firm R\&D Investment: A Survey, Working Paper 12-15 Economic Series, Universidad Carlos III de Madrid, Madrid.

Arrow, K. J. (1962). Economic Welfare and the Allocation of Resources to Invention, [in:] R. R. Nelson (Ed.), The Rate and Direction of Inventive Activity: Economic and Social Factors, Princeton University Press, Princeton, pp. 609-625.

Ali-Yrkkö, J. (2005). Impact of Public R\&D Financing on Private R\&D. Does Financial Constraint Matter?, Working Paper, No. 30, ENEPRI, Brussels.

Bagozzi, R. and Yi, Y. (2012). Specification, Evaluation, and Interpretation of Structural Equation Models, Journal of the Academy of Marketing Science, Vol. 40, No. 1, pp. 8-34.

Cabrer-Borrás, B. and Serrano-Domingo, G. (2007). Innovation and R\&D Spillover Effects in Spanish Regions: A Spatial Approach, Research Policy, Vol. 36, No. 9, pp. 1357-1371.

Catozzella, A. and Vivarelli, M. (2011). Beyond Additionality: Are Innovation Subsidies Counterproductive?, IZA Discussion Paper, No. 5746.

Clausen, T. H. (2009). Do Subsidies Have Positive Impacts on R\&D and Innovation Activities at the Firm Level?, Structural Change and Economic Dynamics, Vol. 20, No. 4, pp. 239-253.

Czarnitzki, D. and Bento, C. L. (2012). Evaluation of Public R\&D Policies: A Cross-Country Comparison, World Review of Science, Technology and Sustainable Development, Vol. 9, No. 2-4, doi: 10.1504/WRSTSD.2012.047690.

Czarnitzki, D., Hottenrott, H. and Thorwarth, S. (2011). Industrial Research Versus Development Investment: The Implications of Financial Constraints, Cambridge Journal of Economics, Vol. 35, No. 3, pp. 527-544.

David, P. A., Hall, B. H. and Toole, A. A. (2000). Is Public R\&D a Complement or Substitute for Private R\&D? A Review of the Econometric Evidence, Research Policy, Vol. 29, No. 4, pp. 497-529.

European Commission (2010). Communication from the Commission. Europe 2020. A Strategy for Smart, Sustainable and Inclusive Growth, COM(2010) 2020 final, Brussels, 3 March.

Eurostat (2016). Retrieved from http://ec.europa.eu/eurostat/statistics-explained/index.php/R $\% 26$ D expenditure

Garcia-Quevedo, J. (2004). Do Public Subsidies Complement Business R\&D? A Meta-Analysis of the Econometric Evidence, Kyklos, Vol. 57, pp. 87-102.

González, X. and Pazó, C. (2008). Do Public Subsidies Stimulate Private R\&D Spending?, Research Policy, Vol. 37, No. 3, pp. 371-389.

Görg, H., and Strobl, E. (2007). The Effect of R\&D Subsidies on Private R\&D, Economica, Vol. 74, No. 294, pp. 215-234.

Greene, W. H. (2008). Econometric Analysis, Pearson Education, New Jersey.

Guellec D. and van Pottelsberghe de la Potterie, B. (2004). From R\&D to Productivity Growth: Do the Institutional Settings and the Source of Funds of R\&D Matter?, Oxford Bulletin of Economics and Statistics, Vol. 66, No. 3, pp. 353-378.

Hall, B. H. and Lerner, J. (2010). Financing R\&D and Innovation, [in:] B. H. Hall and N. Rosenberg (Eds.), Handbook of the Economics of Innovation, Vol. 1, Elsevier, Oxford, p. 611.

Hall, B. H., Mairesse, J. and Mohnen, P. (2010). Measuring the Returns to R\&D, [in:] B. H. Hall and N. Rosenberg (Eds.), Handbook of the Economics of Innovation, Vol. 2, Elsevier, Oxford, pp. 1033-1082.

Jones, C. I. (1995). R\&D-Based Models of Economic Growth, The Journal of Political Economy, Vol. 103, No. 4, p. 759.

Mandl, U., Dierx, A. and Ilzkovitz, F. (2008). The Effectiveness and Efficiency of Public Spending, European Economy Economic Papers 301, European Communities, Brussels.

Martin, M. (2014). Effectiveness of Business R\&D in Emerging Economies. The Review of
Do Public R\&D Expenditures Foster Business R\&D Investments? 
IJSR
Research Evidence, Business and Economics Journal, Vol. 5, p. 116, doi: 10.4172/21516219.1000116.

Radicic, D., Pugh, G., Hollanders, H., Wintjes, R. and Fairburn, J. (2016). The Impact of Innovation Support Programs on Small and Medium Enterprises Innovation in Traditional Manufacturing Industries: An Evaluation for Seven European Union Regions, Environment and Planning C: Government and Policy, Vol. 34, No. 8, pp. 1425-1452.

Romer, P. (1990). Endogenous Technological Change, Journal of Political Economy, Vol. 98, No. 5, pp. 71-102.

Shaw, G. K. (1992). Policy Implications of Endogenous Growth Theory, The Economic Journal, Vol. 102, No. 412, pp. 611-621.

Solow, R. M. (1957). Technical Change and Aggregate Production Function, The Review of Economic Statistics, Vol. 39, No. 3, pp. 312-320. 